\title{
CONTAMINATION OF WATER WITH HELMINTH EGGS: A CASE STUDY OF SOURANI DAM LAKE-TARTUS GOVERNORATE
}

\author{
KANAAN AL-TAMEEMI ${ }^{1 *}$, AMAL DAYOUB ${ }^{2}$, MERVAT MAZLOOM ${ }^{2}$
}

${ }^{1}$ Department of Microbiology, Faculty of Pharmacy, Al-Andalus University for Medical Sciences, Tartous, Syria. ${ }^{2}$ Department of Environmental Protection, Higher Institute for Environmental Research, Tishreen University, Latakia, Syria. Email: d_knaan@yahoo.com

Received: 27 July 2019; Revised and Accepted: 26 August 2019

\section{ABSTRACT}

Objective: In view of the serious prevalence of helminth and ease of infection, our research focuses on the detection of the prevalence of helminth eggs in the Sourani Dam Lake (Tartus governorate) water reflecting the health services and environmental circumstances in this region.

Methods: The study was carried out on water samples of AL-Sourani Dam Lake with the aim to investigate the quality of water from October 2015 to September 2016 and verify the existence of helminth eggs according to their characteristics.

Results: Our results showed a presence of helminth eggs such as Ascaris lumbricoides, Taenia saginata, and Hymenolepis nana in water samples. The total prevalence was $1.57 \mathrm{egg} / \mathrm{L}$. T. saginata eggs were the most prevalent, followed by the eggs of $A$. lumbricoides, while the eggs of $H$. nana were the least prevalent, especially in summer and autumn.

Conclusion: Due to the presence of helminth eggs in samples, it is recommended that sewage treatment plants be established and that health awareness be increased to decrease their prevalence.

Keywords: Helminth, Prevalence, Al-Sourani Dam Lake, Contamination.

(C) 2019 The Authors. Published by Innovare Academic Sciences Pvt Ltd. This is an open access article under the CC BY license (http://creativecommons. org/licenses/by/4. 0/) DOI: http://dx.doi.org/10.22159/ajpcr.2019.v12i10.35101

\section{INTRODUCTION}

According to the World Health Organization (WHO), 133 million people suffer from infection with helminths, especially in developing countries, and $88 \%$ of the reasons are due to decrease in each of the personal hygiene and the use of household sanitation [1,2].

Helminths are worms causing a wide variety of diseases called helminthiases. Helminth eggs are discharged to the environment in feces, the oral-fecal route is the main dissemination pathway of the disease. They enter the body by unpurified drinking water or in uncooked meat or even after swimming or walking on contaminated soil $[3,4]$.

Helminths cause different symptoms according to their species, but generally lead to bleeding and decreasing in blood clotting, abdominal pains, nausea, vomiting, diarrhea, and vitamin deficiency, some studies have shown a loss in weight, height, and hemoglobin in children who infected with Ascaris [5-8].

Some of the helminths live in a simple life cycles (direct, one host) such as Enterobius vermicularis with just one host in which there are growth, development and toreproductionm, or maybe live a complex life cycles such as Schistosoma and Taenia sp. which have an intermediate host where only they grow and develop in addition to definitive host where sexual maturity and reproduction occur $[9,10]$.

Humans are the primary hosts for the helminth infections and most of the helminths reproduce sexually in the human host, producing eggs or larvae that pass out of the body and infect the secondary host $[11,12]$.

\section{METHODS}

\section{Study area description}

AL-Sourani Dam is located in the coastal mountains in the province of Tartus-Syria. It was built in the high part of "Al-Mareiqa" river to the northeast of the Sheikh Badr area about $10 \mathrm{~km}$ west of the town. The dam was established in 2004 with height $41.3 \mathrm{~m}$ and storage volume 4.5 million cubic meters (Fig. 1a and b)

Water samples were collected from study sites monthly during October 2015 to September 2016 from three locations on AL-Sourani Dam Lake (entrance, center, and exit) using clean plastic containers $(10 \mathrm{~L})$ for each location.

Laboratory analysis of helminth eggs in the samples was carried out according to the modified Bailenger method [13] as recommended by the WHO in "Wastewater Analysis for Agricultural Use" [14].

\section{Samples preparation steps}

We left the water samples in the laboratory for $2 \mathrm{~h}$ for precipitation and removed about $90 \%$ of the supernate by pipette, the precipitates were divided into tubes and centrifuged at $1000 \mathrm{~g}$ ( $\mathrm{g}=$ centrifugal force) for $15 \mathrm{~min}$. We reassembled the precipitates in one tube and centrifuged again at $1000 \mathrm{~g}$ for $15 \mathrm{~min}$.

The precipitate was suspended in buffer solution $(\mathrm{pH}=4.5)$ and then we mixed it with ether $(2: 1)$ and centrifuged again to get three layers (precipitate in the down, buffer solution in the middle, and ether in the up), the precipitate was suspended again in zinc sulfate (5:1). Finally, we got the last precipitate by micropipette and put it on McMaster counting slides for examination under a microscope in magnifications $(\times 10, \times 20$, and $\times 40)$.

The numbers of eggs were calculated in a liter of the sample according to the following equation:

$$
\mathrm{N}=\mathrm{AX} / \mathrm{PV}
$$

Where:

- $\quad \mathrm{N}$ is the number of eggs/L of sample

- A is the number of eggs calculated in McMaster counting slide 
- $\quad \mathrm{Z}$ is the final product size $(\mathrm{ml})$

- $\quad P$ is the volume of McMaster counting slide chamber

- $\mathrm{V}$ is the volume of the primary sample (L).

Helminth eggs were identified based on the international classification criteria which were accredited in the classification of helminth eggs (shape, size, and nature of the covering surface), the results were analyzed using the Chi-square test $[10,15]$.

\section{RESULTS}

Our results showed the presence of different types of helminth eggs. By carrying out a morphological and standard assessment of these eggs on the basis of the international classification criteria, we were able to identify three different types of helminths: Eggs of Ascaris lumbricoides which is classified in Nematoda class - Nemathelminthes phylum, and eggs of two species (Hymenolepis nana and Taenia saginata) which were classified to Cestoda class - Plathelminthes phylum.

The eggs of $A$. lumbricoides were readily differentiated by their oval shape, brownish color, and thick outer wall. The size of the eggs was $67 \times 42 \mu \mathrm{m}$ (Fig. 2a), with regard to Taenia sp. We have identified their eggs according to the spherical shape and double-striated wall in addition to the presence of oncosphere within the egg (Fig. 2b); these eggs are expected to belong to Taenia saginata due to the habits of people eating only beef there. The egg of H. nana is characterized by its morphological specifications and we could easily identify it through its spherical shape with a diameter 30-45 $\mu \mathrm{m}$ (Fig. 2c). Its color was gray
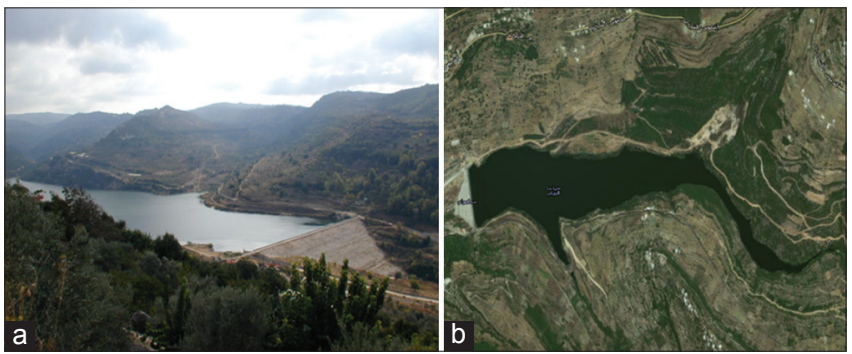

Fig. 1: (a) AL-Sourani Dam Lake (b) AL-Sourani Dam Lake (uploaded by Google earth) and the shell consists of double membrane: Outer smooth and inner thin which spread out between them about 4-8 filaments [10]

Our results showed that the total prevalence of helminth eggs in the water of AL-Sourani Dam was 1.57 eggs/L which is higher than the maximum permissible limit of the WHO (11 egg/L) [16].

T. saginata eggs were the most prevalent at a rate of 2.78 eggs $/ \mathrm{L}$ followed by the eggs of $A$. lumbricoides at a rate of $1.67 \mathrm{eggs} / \mathrm{L}$, Table 1 .

The value of Chi-square test is 0.99 . This suggests a statistically significant relationship between the average of helminth eggs prevalence according to the seasons, we also found that the high prevalence was for Taenia sp. in the summer (4 eggs/L). In general, Taenia sp. had the highest prevalence during the year, whereas $H$. nana had the lowest prevalence, Fig. 3.

\section{DISCUSSION}

Our study confirmed that the eggs of helminths, especially A. lumbricoides, Taenia sp., and H. nana, are the most helminth eggs that recorded in different environmental samples, especially water surface, sewage, and vegetables; this is due to their ability in resistance the external conditions more than other helminth eggs [9]. Our results agree with many other studies $[8,17,18]$

Other studies showed that Ascaris eggs are not the most common helminth eggs. In America, the prevalence of parasitic helminth eggs in wastewater samples was as follows: Ascaris $>$ Toxocara $>$ Toxascaris $>$ Trichuris $>$ Hymenolepis, while the prevalence of helminth eggs in France was as follows: Taenia $>$ Trichuria $>$ Toxocara $>$ Ascaris $[19,20]$.

The presence of eggs has changed during the year and the greatest prevalence in the water of AL-Sourani Dam was in summer and autumn. In Table 1, this is due to water levels low during these two seasons due to decreasing rainfall rates and continuous use of water for irrigation, thus increasing the concentration of contamination in water, including helminth eggs, especially with uncontrolled access of some local wastewater to the lake in a direct or indirect way.

\section{CONCLUSION}

Our results showed that human waste that is thrown directly without treatment into AL-Sourani Dam water or into its tributaries makes

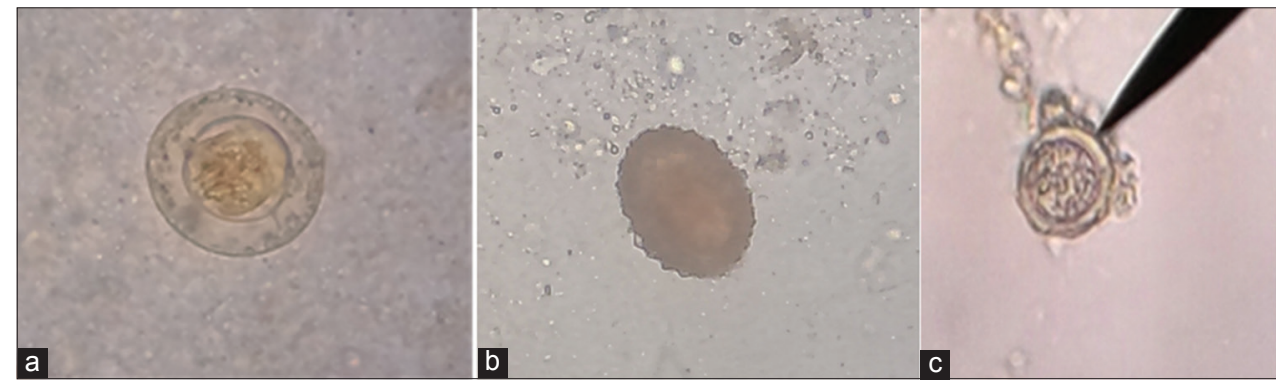

Fig. 2: (a) Ascaris lumbricoides egg. (b) Taenia sp. egg. (c) Hymenolepis nana egg

Table 1: Average of helminth eggs prevalence during the year

\begin{tabular}{lllll}
\hline \multirow{2}{*}{ Season } & \multicolumn{2}{l}{ Average of eggs prevalence during the seasons } & \multirow{2}{*}{ Total prevalence rate eggs/L } \\
\cline { 2 - 4 } & Taenia sp. & A. lumbricoides & Hana \\
\hline Winter & 0.27 & 0.76 & 1.56 & 0.86 \\
Spring & 0.47 & 1.56 & 2.23 & 1.42 \\
Summer & 0.07 & 1.78 & 3.33 & 1.95 \\
Autumn & 0.23 & 2.56 & 2.78 & 2.04 \\
Number of registered eggs/L & 0.26 & 1.67 & 1.57 & \\
\hline
\end{tabular}

A. lumbricoides: Ascaris lumbricoides, H. nana: Hymenolepis nana 


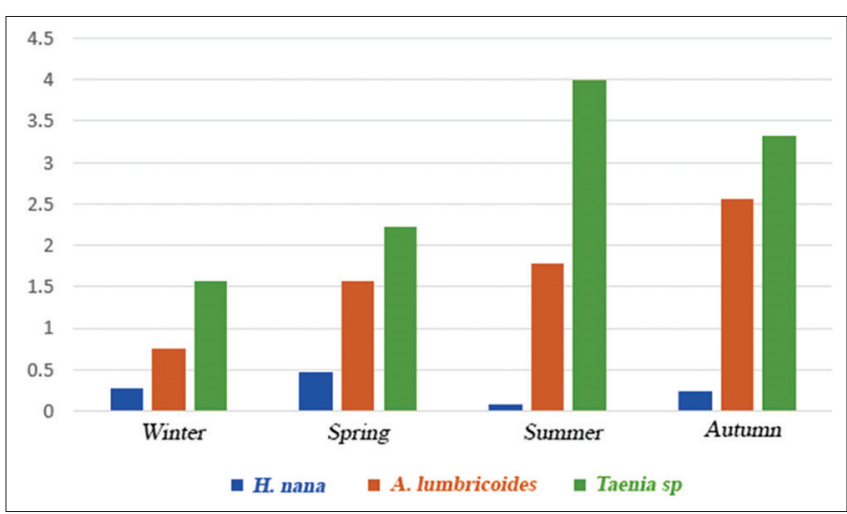

Fig. 3: Average of helminth eggs prevalence during the year

water unsafe for drinking or even for irrigation. Our results showed that the total prevalence of helminth eggs in the water of AL-Sourani Dam was higher than the WHOs maximum permissible limit [16]. The density of helminth eggs in water is used as an indicator of water quality and thus the possibility of disease infections. Therefore, we recommend the establishment of sewage treatment plants and prevention of contaminated water flow and the conduct of periodic examination of water $[10,15,18,21-24]$. Besides, the development of drugs used in therapy [25].

\section{AUTHORS' CONTRIBUTIONS}

Authors have contributed to manuscript article preparation and editing.

\section{CONFLICTS OF INTEREST}

We declare that there are no conflicts of interest.

\section{REFERENCES}

1. Barwick RS, Levy DA, Craun GF, Beach MJ, Calderon RL. Surveillance for waterbornedisease outbreaks. MMWR Surveill Summ 2000;49:1-21.

2. World Health Organization. Training Manual on the Diagnosis of Intestinal Parasites, Based on the WHO Bench Aids for the Diagnosis of Intestinal Parasites, Schistosomiasis and Intestinal Parasites Unit Division of Control of Tropical Diseases, Geneva: World Health Organization; 2004.

3. Sugianto R, Sukarno V, Sudarmaja M, Swastika K. Water source as the main risk factor of soil-transmitted helminths infection on primary school students in Antiga village, Bali. Asian J Pharm Clin Res 2019;12:119-21.

4. Ryabokon EV, Onishchenko TE, Ushenina LO, Furyk EA, Mashko OP, Manual of Helminthiasis. Ministry of Public Health Service Zaporozhyan State Medical University Departement of Infectious Diseases; 2013. p. 66.

5. World Health Organization. Soil-Transmitted Helminth Infections. Available from: https://www.who.int/news-room/fact-sheets/detail/ soil-transmitted-helminth infections. [Last accessed on 2019 Mar 14].

6. Hotez PJ, Brindley PJ, Bethony JM, King CH, Pearce EJ, Jacobson J, et al. Helminth infections: The great neglected tropical diseases. J Clin Invest 2008;118:1311-21.
7. Becker SL, Vogt J, Knopp S, Panning M, Warhurst DC, Polman K, et al. Persistent digestive disorders in the tropics: Causative infectious pathogens and reference diagnostic tests. BMC Infect Dis 2013;13:37.

8. Ribas A, Jollivet C, Morand S, Thongmalayvong B, Somphavong S, Siew CC, et al. Intestinal parasitic infections and environmental water contamination in a rural village of Northern Lao PDR. Korean J Parasitol 2017;55:523-32.

9. Parker GA, Ball MA, Chubb JC. Evolution of complex life cycles in trophically transmitted helminths. I. Host incorporation and trophic ascent. J Evol Biol 2015;28:267-91.

10. Moodley P, Archer C, Hawksworth D. Standards Methods for the Recovery Enumeration of Helminth Ova in Wastewater, Sludge, Compost and Urine Diversion Waste in South Africa, Water Research Commission Report No.TT322/08 2008. p. 33.

11. Manke MB, Dhawale SC, Jamkhande PG. Helminthiasis and medicinal plants: A review. Asian Pac J Trop Dis 2015;5:175-80

12. Centers for Disease Control and Prevention. Parasites Soil-Transmitted Helminths. Available from: https://www.cdc.gov/parasites/sth/index. html. [Last accessed on 2013 Jan 10].

13. Bailenger J. Valeur compare des methods d'enrichissement en coprologie parasitaire. Pharm Biol 1962;3:249-59.

14. World Health Organization. Analysis of Wastewater for Use in Agriculture, A Laboratory Manual of Parasitological and Bacteriological Techniques Geneva: World Health Organization; 1996. p. 31.

15. Mahvi AH, Kia EB. Helminth eggs in raw and treated wastewater in the islamic republic of Iran. East Mediterr Health J 2006;12:137-43.

16. World Health Organization. Guidelines for the Safe Use of Wastewater, Excreta and Greywater in Agriculture and Aquaculture, Guidelines to use Wastewater and Excreta to Fertilize Soils Intended for Agriculture or Ponds used for Aquaculture are presented. Vol. 1, 2, 3, 4. Ed. Paris, France: World Health Organization; 2006.

17. Pullan RL, Smith JL, Jasrasaria R, Brooker SJ. Global numbers of infection and disease burden of soil transmitted helminth infections in 2010. Parasit Vectors 2014;7:37

18. Jimenez-Cisneros BE, Maya-Rendon C. Helminths and sanitation, In: A. Méndez-Vilas A, editor. Communicating Current Research and Educational Topics and Trends in Applied Microbiology. Spain: Formatex; 2007. p. 71.

19. Cabaret J, Geerts S, Madeline M, Ballandonne C, Barbier D. The use of urban sewage sludge on pastures: The cysticercosis threat. Vet Res 2002;33:575-97

20. Madeline M, Ballandonne C, De Pecoulas EP, Guyon R, Malas JP, Tourte Schaeffer C, et al. Etude parasitologique des boues residuaires urbaines: mise en evidence de la viabilite des aeufs de Taeniides. Bull Soc Parasitol 2001;19:1. Available from: http://www.Tours.inra.fr/ sfpar/bulletin.htm.

21. Konate Y, Maiga AH, Wethe J, Basset D, Casellas C, Picot B, et al. Sludge accumulation in an anaerobic pond and viability of helminth eggs: A case study in burkina faso. Water Sci Technol 2010;61:919-25.

22. Ligocka A, Paluszak Z. Effectiveness of different sanitisation technologies on the inactivation of Ascaris swum eggs in organic waste. Bull Vet Inst Pulawy 2009;53:641-4.

23. Hatam-Nahavandi K, Mahvi AH, Mohebali M, Keshavarz H, Mobedi I, Rezaeian M, et al. Detection of parasitic particles in domestic and urban wastewaters and assessment of removal efficiency of treatment plants in Tehran, Iran. J Environ Health Sci Eng 2015;13:4.

24. Pérez EZ, Rojas-Valencia N, Chairez I, Torres LG. Coliforms and helminth eggs removals by coagulation-flocculation treatment based on natural polymers. J Water Resour Prot 2013;5:1027-36

25. Gupta JK, Mishra P. Antimicrobial and anthelmintic activities of some newly synthesized triazoles. Asian J Pharm Clin Res 2017;10:139-45. 